\title{
Practices and attitudes of youth in politics in Epe local government, Lagos State, Nigeria
}

\author{
Latifat Apeke Saka, Bola Sebiomo \\ Department of Social Studies, Michael Otedola College of Primary Education, \\ Noforija - Epe, Lagos State, Nigeria
}

\begin{abstract}
Politics is a necessary result of man's relationship with each other, it is everywhere and influencing the affairs of human being, it is a means by which an individuals or group of people achieve and maintain power and influence positively the socio-economic status of the parties concerned. This paper reports the practices and attitude of youth in politics in Epe local government area, Lagos state. From the study fifty (50) youths were randomly selected from five zones, ten (10) youths from each zone in Epe Local area. Each technique contained four items. Findings shows that youth wing of political parties came first under political attitudes while violence came first with mean score of 2.58 under youth anti-social behavior in politics followed by maltreatment of youth in the society with mean score of 2.98 under the causes of youth negative behaviors in politics, introducing programme of protection to youth came first with the mean score of 3.74 under how could government of Nigeria help the youth to become an instrument for natural rebirth. There is significant difference between male and female views in causes and solution to youth problems in politics. There is no significant difference between male and female views in the practices and attitudes of youth in politics. It is recommended that Government should enlighten the youth on how to practice politics without violence more so National rebirth could be advanced if also organize seminars and workshop for the youths.
\end{abstract}

Keywords: Politics; Practices; Attitudes; Youth; Population; Violence

\section{INTRODUCTION}

The definition of youth is not universal because the definition depends on each nation $\mathrm{s}$ objectives, condition and realities particularly the historical and contemporary issues that need to be addressed. The Encyclopedia dictionary defines youth as the condition of being young, the period of life from puberty to the attainment of full growth". The youth are those in the period between childhood and maturity (Yinusa, 2001). In another sense, Youth refers to the segment of the nation with potential and virile energy and strength required in propelling the nation by way of enhancing its productivity and development. Youth are those between ages of 15 and 64 years (Aremo, 2004).

In Nigeria, the youth comprises all young persons of ages 18 to 30 years and who are citizens of the Federal Republic of Nigeria (FRN, 2001). According to 1999 population 
census, the country,,$^{\text {ee }}$ population is predominantly young. Six out of ten Nigerians are under twenty- five years of age. Consequently, this represents the most active, volatile and yet the most vulnerable segment of the population to anti social behaviours, chaps and violence. Nigerian youth have been rendered redundant because of joblessness. Most of them are not functioning members of society. Consequently, brains that are supposed to be used for useful contribution in society are being diverted to active robbery, forgery, political thuggry, sexual and drug abusers (Adeola, 2001).

Oyekunle, (2010) defines attitude as the opinions and feelings that are usually about something. It is also the way one behaves towards someone during a particular situation most importantly when this shows how one feels, Attitude could either be a positive or negative feeling which consists of a carefully considered opinion, judgment or towards a social object, human being, a subject or a proposition which includes peoples thought and opinion about something. The way and manner we respond to situations around us is a function of our attitude (Kneeling 1999). Attitude is a predisposition to respond positively or negatively to people, objects or ideas in one ${ }^{e e}$ environment. These are in such areas as cognitive talks about the knowledge one has about the attitudinal person, objects or idea. The effects are the feelings one has about the attitudinal objects, persons or things (Ake, 2001). Attitude therefore comprises the ideas, beliefs, opinions and value which an individual has, the feelings and emotions connected with these and the behavioural tendency towards the object. To a large extent, the attitude of an individual will affect him / her group as well as society. If he has positive attitude towards the groups there is a high tendency that he will experience some success. Negative attitudes towards the groups and members usually imply that an individual's interests and energies are diverted elsewhere and he will resist to every move to make him belong.

Attitudes can be rational or sometimes irrational and they are very persistent and durable both in time and in intensity (Alake, 2000). In recent times, however, the patriotic characters of the youth became intermittently weakened on the basis of the prevailing circumstances occasional majorly by the long period of military rule. Nigerian youth of today are entangled in the ideological construct which have mortgaged their intrinsic progressive traits by which they were previously identified. Pressed by the myriad of socio-economic problems facing the nation, the youth in recent times are obviously apathetic and political non-chalant. They have become religious fanatics, drug abusers, currency traffickers, miracle seekers and of course dwellers in cultism and all sorts of clandestine activities. Nationalism and patriotism became a thing of the past (Aremo, 2004).

A review of the dynamic traits of Nigerian youth in the process of nation building portrays a picture of activism. The roles of the youth are typified by a period of workable rapport and understanding between the constituted authority and elemental politic inherent in the system. In the traditional society, for instance, the youth age-grade were usually organized as a recognized group and given specific duties by the society (MAMSER, 2001). The youth were essentially trained and mobilized for different activities ranging from administration, defense, farming, a rituals to entertainment. Therefore, the administrative involvements of the youth in the traditional political system especially in the pre-colonial period of Nigeria were quite encouraging. The political system therein was essentially participating (Anifowose, 2003).

On the basis of the youth 's militant input as exemplified by their determined struggle against imperial domination, exploitation and dictatorial rule by which the British merchants cheaply exploited their labour power for the formeres economic interests, nationalist agitations became buttressed shortly after independence in 1960 . The youth yet demonstrated 
their usual patriotic posture opposed the signing of the Anglo-Nigerian defense fact (MAMSER, 2002). The youth were essentially trained and mobilized for different activities ranging from administration, defense, farming, and entertainment. Therefore, the administrative involvements of the youth in the traditional political system especially in Epe of the pre-colonial period, Nigeria were quite encouraging. But considering their administrative involvement with the modern political system of government the reverse is the case. This may be due to the problem of unemployment, poverty, economic meltdown, selfish-interest, godfathers, egotism which is the order of the day, make them to turn politics into do or die affairs.

Politics can be defined as a pervasive human activity in which individuals and groups seek access to authority, power and control. This definition implies that in every society there is a body of persons vested with authority and power to regulate, control the day to day activities and protect the people in the state.

Representative government became imperative as it is no more possible for everybody to gather in one place in order to take decision to govern the state as a result of large size and population of modern states (Ololobou, 1999).

Yinusa, (2001) observes that citizens se participation in this type of government takes the form of active participation in which the participants are known as political activists. He noted that citizenship participation takes different forms of belongings to political parties, contesting in elections, sponsoring of political parties, holding of public offices, observatory postures and so on. In Nigeria, the Clifford constitution of 1992 introduced the elective principle into the Nigeria political system, he provided some measure of participatory democracy in preindependence period in Nigeria politics. In human circumstances, it manifests itself in human endeavours. No wonder, some people believe that every human being is a political animal. Politics influence the life of all of us, regardless of whether or not one participates in the political process. In fact, one of the greatest philosophers, Aristotlle (337Bc) characterized man as a political being.

Politics is a necessary result of man 's relationship with each other. Because politics is everywhere and influencing the affairs of human being, Aristotle (337Bc) regarded it as the master science.

He emphasized that political dimension of human existence. i.e the most important dimension is that politics decidedly conditions the other circumstances. Politics could be defined as a means by which an individuals or group of people achieve and maintain power and influence positively the socio-economic status of the parties concerned (Jonah, 2009).

A review of the dynamic traits of the Nigerian youth in the process of nation building portrays a picture of activation, idealism and indeed nationalistic tendency.

The roles of the youth are filled by a period of workable report and understanding between the constitute authority and elemental politics inherent in the system. In the traditional society, like Epe for instance, initial stage of politics, the youth age grade was usually organized as a recognized group specific duty by the society.

\section{PURPOSE OF THE STUDY}

The main purpose of this study is to examine the practices and attitude of Epe Youth in politics. The study also explores the underlying causes of youth behavior in politics. 


\section{RESEARCH QUESTIONS}

- What are the practices of Epe youth in politics?

- Do the Epe youth engage themselves in any negative antisocial behavior in their political ways of life?

- What are the causes of youth negative behavior in politics?

- How could the government of Nigeria help the youth to become an instrument for national rebirth in politics?

\section{METHOD}

The research design is descriptive survey. It surveys Epe youths practices and attitude in politics in Epe Local Government Area. The sample of this study consisted of fifty (50) youths that were selected from five (5) zones in Epe Local Government Area. Among the youths, ten (10) of them have masters degree (M.A, M.Ed, M.Sc), 30 have (Bsc, Bsc (Ed), B.A) and 10 are NCE holders. They were 22 Females and 28 males. The instrument was questionnaire which asked them to rate the practices of Epe youth in Politics, the anti-social behaviors in their political ways of life, the causes of youth negative behavior in politics and how government of Nigeria could help the youth to become an instrument for national rebirth in their practices and attitude towards politics. Fifty questionnaires were administered to fifty youth in Epe and Eredo Local Government, Lagos state. The information gathered from the respondents were analyzed using descriptive and inferential statistics.

\section{FINDINGS}

\section{1. Research question 1}

What are the practices of Epe youth in politics? The Practices of Epe youth in political engagements are presented in Table 1.

Table 1. Practices of Epe Youth in politics. The table below shows four different items under Political attitudes.

\begin{tabular}{|c|c|c|c|c|}
\hline Youth practices & $\mathrm{N}$ & Mean & Rank & Std Dev. \\
\hline Youth wing of political parties & 50 & 3.04 & $1^{\text {st }}$ & 1.04 \\
\hline $\begin{array}{c}\text { Active participation in electioneering } \\
\text { campaign }\end{array}$ & 50 & 2.94 & $2^{\text {nd }}$ & 1.07 \\
\hline Distribution of posters & 50 & 2.92 & $3^{\text {rd }}$ & .92 \\
\hline Hooliganism and thuggrey & 50 & 2.64 & $4^{\text {th }}$ & 1.22 \\
\hline
\end{tabular}

From table 1, four political behaviours were tested; behavior of forming the youth wing of political parties came first with the mean score of 3.04, because the youth believed that they can only gain what they want from the government by giving them their full support. Followed by active participation in electioneering with the mean score of 2.94, while 
distribution of posters came third with the mean score of 2.92, and hooliganism and tuggrey came forth with the mean score of 2.64 .

\section{2. Research Question 2}

Do the youth engage in antisocial behaviors in their political activities?

Table 2. Youth Antisocial Behaviour in Politics.

\begin{tabular}{|c|c|c|c|}
\hline & MEAN & RANK & $\begin{array}{c}\text { STD. } \\
\text { DEV. }\end{array}$ \\
\hline Violence & 2.58 & $1^{\text {st }}$ & 1.052 \\
\hline $\begin{array}{c}\text { Hooliganism in politics } \\
\begin{array}{c}\text { Criminal behaviours during political } \\
\text { processes }\end{array}\end{array}$ & 2.26 & $2^{\text {nd }}$ & 1.084 \\
\hline Thurgery in politics. & 1.94 & $3^{\text {rd }}$ & 1.010 \\
\hline
\end{tabular}

From table 2, four different political practices, are listed: this came first with the mean score of 2.58, They engage in this because they want to prevent rigging of election, they believe that if they did not act in this way they will not get the right person to represent them. Hooliganism in politics came second with the mean score of 2.26 , it is followed by criminal behaviours during political processes which came third with the mean score of 2.20 . Thurgery in politics also came forth with the mean score of 1.94 .

\section{3. Research Question 3}

What are the causes of youth negative behavior in politics?

Table 3. Causes of Youth Negative Behaviours in Politics.

\begin{tabular}{|c|c|c|c|}
\hline & MEAN & RANK & STD. DEV \\
\hline Maltreatment of youth in the society & 2.98 & $1^{\text {st }}$ & .869 \\
\hline $\begin{array}{c}\text { Acts of favourism and nepotism among } \\
\text { political leaders }\end{array}$ & 2.92 & $2^{\text {nd }}$ & .829 \\
\hline Oppression of Epe youth in politics. & 2.86 & $3^{\text {rd }}$ & .857 \\
\hline Acts of corruption among political leaders. & 2.82 & $4^{\text {th }}$ & 1.063 \\
\hline
\end{tabular}

Among the causes of youth negative behavior, maltreatment of Epe youth came first with the mean score of 2.98. The reason for this may be in order to secure their votes to the right person they want to be there. Acts of favourism and nepotism among political leaders came second with the mean score of 2.92 while oppression came third with the mean score of 2.86. Acts of corruption among political leaders came forth with the mean score of 2.82 . 


\section{4. Research Question 4}

How could the government of Nigeria help the youth to become an instrument for national rebirth in politics?

Table 4. Instrument for National rebirth.

\begin{tabular}{|c|c|c|c|}
\hline & MEAN & RANK & STD. DEV. \\
\hline $\begin{array}{c}\text { By introducing programme of protection } \\
\text { to youth and taking care of them as well, } \\
\text { national rebirth could be achieved. }\end{array}$ & 3.74 & $1^{\text {st }}$ & .487 \\
\hline $\begin{array}{c}\text { Youth should be made to understand that } \\
\text { politics should not be practiced through } \\
\text { violence. }\end{array}$ & 3.68 & $2^{\text {nd }}$ & .471 \\
\hline $\begin{array}{c}\text { By organizing seminars and workshops } \\
\text { for Epe youths, they tend to become } \\
\text { instrument of national rebirth. }\end{array}$ & 3.36 & $3^{\text {rd }}$ & .942 \\
\hline
\end{tabular}

From the above, three ways of how government can help the Nigerian youth to become active instrument for national rebirth in politics, which include introducing programme of protection to youth and taking care of them as well came first with the mean score of 3.74. This is so because to achieve national rebirth is a sign of promoting unity, peaceful coexistence, understanding and so on. Furthermore it will improve the standard of living of many people and once they have better offer they will feel comfortable and appreciate the government's efforts on masses. Also, Youth should be made to understand that politics should not be practiced through violence came second with the mean score of 3.68 while organizing seminars and workshops for Epe youths, came third with the mean score of 3.36

\section{5. Research Question 5}

Is there any significant difference between the views of male and female in acts of Youth, Causes and Solution to Youth Problems in Politics?

Table 5. The t-test analysis of male and female views.

\begin{tabular}{|c|c|c|c|c|c|c|c|c|}
\hline & SEX & $\mathrm{N}$ & MEAN & STD.DEV. & STD.ERROR & $\mathrm{t}$ & DF & SIG \\
\hline \multirow{2}{*}{ PRACTICES } & $\mathrm{M}$ & 41 & 11.85 & 2.545 & .397 & \multirow{2}{*}{1.758} & \multirow{2}{*}{48} & \multirow{2}{*}{0.085} \\
\hline & $\mathrm{F}$ & 9 & 10.11 & 3.333 & 1.111 & & & \\
\hline \multirow{2}{*}{ ATITUDES } & $\mathrm{M}$ & 41 & 8.83 & 2.635 & .412 & \multirow{2}{*}{.852} & \multirow{2}{*}{48} & \multirow{2}{*}{0.398} \\
\hline & $\mathrm{F}$ & 9 & 9.67 & 2.828 & .943 & & & \\
\hline \multirow{2}{*}{ CAUSES } & M & 41 & 11.85 & 2.265 & .354 & \multirow{2}{*}{1.882} & \multirow{2}{*}{48} & \multirow{2}{*}{0.066} \\
\hline & $\mathrm{F}$ & 9 & 10.33 & 1.803 & .601 & & & \\
\hline \multirow{2}{*}{ SOLUTION } & $\mathrm{M}$ & 41 & 11.05 & 1.264 & \multirow{4}{*}{$\begin{array}{c}.197 \\
.669 \\
2.5668\end{array}$} & \multirow{2}{*}{2.862} & \multirow{2}{*}{48} & \multirow{2}{*}{0.066} \\
\hline & $\mathrm{F}$ & 9 & 9.56 & 2.007 & & & & \\
\hline \multirow{2}{*}{ TOTAL } & M & 41 & 43.83 & 4.159 & & 2.568 & 48 & 0.013 \\
\hline & $\mathrm{F}$ & 9 & 39.33 & 7.018 & & & & \\
\hline
\end{tabular}


This Table 5 shows the level of significant difference between male and female views in the practices, attitudes, causes and solution to youth problems in politics. There is no significant difference between male and female views on the practices of Epe youths in politics. There is no significant difference also between male and female responses to attitude of Epe youth in politics, while there is significant difference between male and female in causes and solution.

\section{DISCUSSION AND CONCLUSIONS}

The above results revealed that youth behaviours in politics include both positive and negative behaviours. Youth wing of Political parties came first with the mean score of 3.04, possibly the youth believed that they can only gain what they want from the government by giving them their full support in form of active participation in the election. But in the anti social behaviour like violence came first with the mean score of 2.58 , may be they want to prevent rigging of election. They believe that if they did not act anti socially they will not get the right person to represent them. Among the causes of youth negative behaviors are maltreatment of Epe youth in politics came first with the mean score of 2.98. The reason for this may be in order to secure their votes to the right person they want to be there and to prevent rigging.

There are various ways by which government can help the Nigerian youth to become a positive instrument for national rebirth in politics. These include introducing programme of protection to the youth and taking care of them as well, making them to understand that youth should not practice politics with violence and organizing seminars and workshop educating the youth on how to achieve national rebirth through politics is another one. The above result revealed that introducing programme of protection to youth and taking care of them as well came first. This is so because to achieve national rebirth requires promoting unity, peaceful co-existence, understanding and so on. Furthermore it will improve the standard of living of many people and once they have better offer they will feel comfortable and appreciate the government's efforts on masses. As suggested by Oyekunle, (2010) that morality should be given utmost consideration in political practice, he said only this can make the citizens to have faith and hope in the leadership of the country, and restore their confidence in the political elites and also promote the political and moral obligation of both the citizens to the state and the state to the citizens. Troy, (2013) also suggested that political behavior can also influence the Biology in politics. There is no significant difference between male and female responses to practices, attitude, causes of criminal behaviours of Epe youths in politics and solution to the anti-social behaviours. It is recommended at this juncture that Government should enlighten the youth on how to behave in politics without violence. The youth need to be orientated on the importance and benefits of politics and that they can only get what they want from government through their full support.

\section{References}

[1] Adeola, E.O. (2001). "social Redundancy among Nigeria youths (Revised Edition), Akolaz Enterprises: Lagos.

[2] Ake, C.I (2001). The Political Context of Indigenization, Hutchinson \& Co Limited: Ibadan. 
[3] Anifowose R. (2003). Elements of Politics, Iroanusi publications, Lagos

[4] Alake, A.A. (2000). Citizenship education for Tertiary Institutions: Print Arts Limited, Lagos.

[5] Aremo, A.G. (2004); "The Structure of Youth unemployment in the context of Economics Development: The Nigerian experience," a paper presented at the maiden National Conference of the school of Arts and Social Science, At Adeyemi College of Education, Ondo.

[6] Badejo, A.A. (1990); Involvement and Commitment in Non programme, "in ingwuedu, DEC (ed) National orientation movement Lagos: Federal Government press.

[7] F.R.N./Federal Republic of Nigeria (2007) "The National Policy on Education," Lagos/Abuja: Federal Government Press and NERDC.

[8] Kneeling, M. (1999): Personnel Practices Affecting Employee "Cincimati, SouthWestern Publishing.

[9] MAMSER (2002). "Youth, An instrument of National Development, print Arts Limited, Lagos.

[10] Ololobou, Y.P.S. (1999) Political Socialization in Nigeria In Mezieobi. K.A (ed) Concerns and insights out Publishers.

[11] Oyekunle, A.O. (2010). Machiavellian politics and the Idea of Public Morality in Nigeria. International Journal of Multi-disciplinary Research: Post-graduate school, Ago-Iwoye, vol. iii (1\&2) p. 46.

[12] Yinusa K.(2001): “A Consideration of Some Factors Associated with youth Involvement in Ethnic crises Implication for Social Studies Education" a paper presented at National Conference at Adeyemi College of Education; Ondo.

[13] Troy D., Journal of American Political Science Association 11(2) (2013) 497.

[14] Tomáš Hes, Anna Poledňáková, International Letters of Social and Humanistic Sciences 2 (2013) 18-31.

[15] Mohsen Mehrara, Masoumeh zirak, International Letters of Social and Humanistic Sciences 2 (2013) 32-38.

[16] Taiwo Adewale Muritala, Ismail O. Fasanya, International Letters of Social and Humanistic Sciences 2 (2013) 39-50.

[17] Borowski A., International Letters of Social and Humanistic Sciences 3 (2013) 46-53.

[18] Borowski A., International Letters of Social and Humanistic Sciences 3 (2013) 69-74.

[19] Donovan A. McFarlane, International Letters of Social and Humanistic Sciences 4 (2013) 35-44.

[20] Rajesh K. Yadav, Nishant Dabhade, International Letters of Social and Humanistic Sciences 4 (2013) 49-69.

[21] Borowski A., International Letters of Social and Humanistic Sciences 4 (2013) 70-74.

[22] Paul Bukuluki, International Letters of Social and Humanistic Sciences 5 (2013) 27-44.

[23] Mohsen Mehrara, Maysam Musai, International Letters of Social and Humanistic Sciences 5 (2013) 55-62.

[24] Debiprasad Mukherjee, International Letters of Social and Humanistic Sciences 6 (2013) 41-48.

[25] Tomáš Hes, Alena Neradová, Karel Srnec, International Letters of Social and Humanistic Sciences 7 (2013) 55-75.

[26] Kinga Dziwańska, International Letters of Social and Humanistic Sciences 7 (2013) 96-112.

[27] Borowski A., International Letters of Social and Humanistic Sciences 7 (2013) 113-118. 
[28] Mohsen Mehrara, Maysam Musai, International Letters of Social and Humanistic Sciences 8 (2013) 1-7.

[29] Jacek Tittenbrun, International Letters of Social and Humanistic Sciences 11 (2013) $10-34$.

[30] Mohsen Mehrara, Hamid Abrishami, Mostafa Boroujli, Mahan Amin, International Letters of Social and Humanistic Sciences 11 (2013) 76-83.

[31] Borowski A., International Letters of Social and Humanistic Sciences 11 (2013) 100-105.

[32] Sele Sylvester Ebisin, International Letters of Social and Humanistic Sciences 2 (2014) $1-9$.

[33] Tittenbrun J., International Letters of Social and Humanistic Sciences 2 (2014) 20-40.

[34] Borowski A., International Letters of Social and Humanistic Sciences 2 (2014) 110-121.

[35] Pawa Tersoo, International Letters of Social and Humanistic Sciences 3 (2014) 26-36.

[36] Rabiee u Muhammad Ishaq, International Letters of Social and Humanistic Sciences 3 (2014) 37-44.

[37] Adoga James Ada, International Letters of Social and Humanistic Sciences 3 (2014) 45-52.

[38] Bahram Meihami, Hussein Meihami, International Letters of Social and Humanistic Sciences 3 (2014) 80-91.

[39] Onyike Maggaret Odu, International Letters of Social and Humanistic Sciences 4 (2014) 31-39.

[40] Uloma Charity Oguzor, International Letters of Social and Humanistic Sciences 4 (2014) 97-104.

[41] Okezie A. Ihugba, Alex Odii, A. C. Njoku, International Letters of Social and Humanistic Sciences 5 (2014) 21-34.

[42] Okezie A. Ihugba, Bankoli Bankong, N. C. Ebomuche, International Letters of Social and Humanistic Sciences 5 (2014) 92-113. 